\title{
Evaluation as One of the Key Aspects of Primary School Education
}

\author{
Martin SKUTIL ${ }^{1, a,{ }^{*}}$ \\ ${ }^{1}$ Institute of Primary and Pre-primary Education. Faculty of Education, University of Hradec \\ Králové, Rokitanského 62, 50003 Hradec Králové, Czech Republic \\ amartin.skutil@uhk.cz \\ ${ }^{*}$ Corresponding author
}

Keywords: Primary education, evaluation, types of evaluation, forms of evaluation, teacher

\begin{abstract}
School evaluation is an important part of quality education. In essence, evaluation is a feedback for the evaluated individual on the quality of their performance, results and efficiency of their performed work, but it also contributes to the development of the personality of the pupil and their self-evaluation ability, which can be applied throughout their future life. The aim of this paper is to highlight the importance of the quality of providing feedback in school education and to find out how teachers currently use evaluation in pedagogical practice, what are the motives of their choice and what positives and negatives they see in singular forms and types of evaluation. Based on a qualitative survey conducted through a semi-structured interview, I show how teachers perceive the different forms and types of evaluation and the reasons for their use in pedagogical praxis. It turns out that teachers still mainly use quantitative evaluation, which they almost regularly supplement with qualitative forms. The main reason is to shape pupils' personality and to support their ability to realise mistakes and learn from them in the future.
\end{abstract}

\section{Introduction}

Evaluation is an integral part of every human activity and together with the decision-making process, affects every person's behaviour. Evaluation is a natural part of any educational activity and influences a pupil's personality and social development.

Evaluation in teaching significantly influences the quality of the educational process. Teachers can assess the success of teaching as well as plan other learning objectives and the means of their fulfilment, namely the content of teaching, choice of methods and organisational forms. It provides pupils with important information about their own progress, it's crucial for motivating pupils to learn and it also participates in the creation of pupil's self-concept.

Evaluation is a complex activity that includes elements of orientation, decision-making between options, understanding, appreciation, organisation, engagement, reaction to facts, etc. Processes in the evaluation are also permeated by cognitive and affective components. The relationships, the preferred values of evaluators and pupils being evaluated, the experiences and attitudes towards life, as well as the moral-free features that are essentially formed from birth by the family model of education, and which can be very different at superficial comparison and are definitely included in the evaluation. For this reason, I consider the evaluation to be a very complex activity in which it's not possible to be unprepared and uninformed by basic information. 


\section{Theoretical Basis}

According to Kolár \& Šikulová [1], the evaluation act can be formulated as activity, operation and activity which:

- follows a goal (e.g. it wants to influence a pupil's personality quality).

- is done under certain conditions (the specific nature of the teacher-pupil relationship).

- is carried out by certain means (verbal evaluation, mark, points ...).

- leads to a certain result (the pupil responds in some way to the evaluation, takes an internal opinion, accepts or doesn't accept the evaluation).

We can derive a high degree of evaluation from the so-called Bloom Taxonomy of Educational Objectives, where evaluations, achievement of the capacity to conduct evaluation judgments, assess situations, activities and personality phenomena are at the top of the hierarchy of cognitive goals. In addition, the processes (in manifestations) of evaluation are significantly influenced by both cognitive and affective components. Evaluations are also influenced significantly by the experiences, attitudes, views, relationships and values of the evaluators as well as the individuals being evaluated [2].

School evaluation has many forms and relates to many different relationships in the school system. This is, in fact, a special case of evaluation. Everything applies to it regarding the general definition of evaluation and it also has its own specifics [3]:

- It concerns a unique social institution - schools.

- It relates to a particular process - teaching.

- It relates to special teaching factors - pupils and teachers.

The definition of evaluation functions is very broad and there are terminological breakthroughs. Pupil evaluation should support pedagogically desirable activities or procedures and, on the contrary, mitigate unwanted behaviour. Depending on this, the relevant functions and the corresponding types of evaluation are defined that teachers can choose with regard to their pedagogical intentions (Průcha, 2009).

- Motivational. It's the most popular and most widely used evaluation feature. According to Čáp \& Mareš [4], motivation is based on human needs, especially the needs of social nature. These include the needs of personal relationships, performance, success, recognition, respect and self-esteem, the need to be positively evaluated and accepted. Therefore, evaluation's motivational significance is considerable in the school environment.

- Informative. Mareš [5] refers to the feedback as to a situation whereby, after doing something, the pupil receives information from others regarding the course and result of their activities. Feedback may be continuous or a summary.

- Regulatory. It's the deliberate influence of the pupil's work, especially the continuous work. It focuses on the intensity of pupil activity, the use of methods and learning practices.

- Educational. It's seen in the formation of a pupil's positive attributes and attitudes towards themselves and their surroundings.

- Prognostic. On the basis of a thorough analysis of pupils' performance, it's possible to pronounce pupil's other study perspectives. 
- Differentiation. School evaluation allows pupils to be differentiated into certain homogeneous groups, which for example, are characterised by different levels of curriculum mastery.

In recent years, the informative function has been overestimated within the evaluation to the detriment of the formative function. This is the consequence of the transmissive concept of education. In this light, the issue of evaluation has been narrowed down to the issues of testing and classification. Testing has become a basic form of learning outcomes and the mark has been the primary goal [6]. We can distinguish two basic approaches to evaluation - quantitative and qualitative:

- Quantitative evaluation in Czech education is represented mainly by classification. The problem is that it's generalising information that usually doesn't take a whole range of the pupil's characteristics into account and reduces its perceptual value. The mark is only a formal reflection of the expression of a very complex evaluation process. Other options for quantitative evaluation include, for example, the number of points that are often used in tests, the percentage expression or the count of good/bad answers.

- Qualitative evaluation is usually associated with verbal evaluation. Verbal evaluation shouldn't just contain information regarding the learning outcomes achieved but also includes pupils' attitudes and efforts. Its advantage is that it can better capture the individual progress of each pupil and provide more solid information concerning their strengths and weaknesses. Verbal evaluation can be used as both continuous as well as final. In addition to these positive features, verbal evaluation is demanding for the teacher, there is a risk of slipping to use cliché or using it to rewrite the mark. Qualitative forms of evaluation can also include a portfolio showing progressive pupil development with respect to the quality of the materials in the portfolio [7].

In Czech and foreign literature, we meet with different ratings of evaluation types. The authors very often mention the following types [1.3]:

- Formative evaluation can be any evaluation that provides useful information on the pupil's current knowledge and skills. Useful especially in the sense that they will know what their current level is and what needs to be known for learn something else. Formative evaluation can't end up at the distinction as offered by classification, but it's necessary to inform pupils in regard to what they have learned, as well as what they haven't learned yet and get advice on how to carry on in learning. The main argument for the use of formative evaluation is that in turn, pupils achieve better results, the working climate in the classroom improves and pupils learn to accept evaluation as a natural part of life [8].

- Summative (final) evaluation determines the level of knowledge achieved over a certain period of time, usually at the end of a specific teaching period.

- Normative evaluation is focused on the performance of one pupil in relation to the performance of other pupils. For example, one tenth of pupils get the best mark, no matter what the real level of performance was.

- And a number of others that are used differently

Self-evaluation represents a relationship to one's own, and for this reason it's an important factor in the psychological regulation of behaviour and experience. It's a product and, at the same time a factor influencing intrapersonal processes. Quality evaluation teaches self-evaluation. The essence of self-evaluation is that pupils are responsible for their learning 
and are actively involved in the process of learning and evaluation. The basis for self-evaluation development is self-knowledge while an important role is also played by the evaluations of teacher and classmates [9].

Rakoušová [10] reminds that the point of self-evaluation lies in dealing with error. It's always necessary to analyse the error and to look for the cause. Thanks to this, it's possible to choose the teacher's individual approach. When it comes to work in the lesson, every activity is immediately checked directly with the pupils, who is led to discover the error themselves or immediately after a warning. If the pupil can't find the error, the teacher points it out to them.

\section{Methodology}

In line with current educational trends and the pressure on the use of formative evaluation in schools, I have decided to carry out a research survey and understand how teachers currently use evaluation in pedagogical practice, what are motives of their choice and what positives and negatives they see in singular forms and types of evaluation.

In view of the questions raised, the qualitative methodology that helps to understand the nature of the phenomenon seems to be the most appropriate approach to exploration.

\section{Research Sample}

The selection of the research group was designed to include teachers with up to five years practical experience, with practical experience between five and fifteen years and practical experience more than fifteen years. At the same time, one of the respondents teaching in a small school that is specific in its conception, teaching at school in a medium-sized community and a third one to teach in a large urban primary school. In total five semi-structured interviews were conducted.

\section{Instrument and Procedures}

A semi-structured interview was used as a research method. Respondents were not informed in advance of the specific questions to be used in the interview. The only information was the topic of "Evaluation in primary school" in order to prevent respondents from preparing answers in advance for the questions and therefore responding naturally and immediately. All the interviews were recorded on a recorder. The responses were subsequently rewritten, while the respondents' non-verbal responses were recorded [11]. In order to preserve anonymity, the changed respondents' first names were used in the interview transcripts and the respondents' primary schools were not identified.

\section{Data Analysis}

For the analysis and processing of the obtained data, a constant comparison method was used, which is based on the continuous comparison of the obtained answers in interviews, the search for differences and similarities or the possible matches. This method is suitable for the analysis of the selected research and corresponds most to the intention of comparing respondents' answers and to create a more general opinion for the question asked [12].

\section{Limitation of a Study and Ethical Principles}

Like any qualitative study, we can also find limitations that arise from the nature of the research. The greatest deficiency is, of course, the subjectivity of the responses. Although it was 
an attempt to select a representative set of respondents, their personal experiences and the specifics of the school where they work, were obviously reflected in their answers. Both the respondents' experiences as well as the philosophy of the school where they work and the pressure of parents and pupils, who can affect the evaluation system to a certain degree.

The ethical aspect has already been outlined above. However, it's worth recalling that, with regard to the possible identification of respondents, their first names were changed in the interview transcripts and the identity of the primary school where the respondent works was not revealed.

\section{The Research Results}

The analysis of the interviews reveals several interesting facts which point to the change in the use of evaluation in Czech schools. It turns out that teachers increasingly put more emphasis on the formative elements in the evaluation at the expense of the classical quantitative expression of the results. This fully corresponds to the current trends in the changing education system, moving from mere learning knowledge to the level of pupil development as an individual personality. On the other hand, it's still true that parents and pupils traditionally require a mark as a symbol of school success or failure.

For me, any evaluation is intended to inform the pupil and parents about how they are doing to motivate them towards better performance. Informative, motivational character. In order for these children to also learn self-evaluation, so I compare how they evaluate themselves with how I evaluate them (Lucia)

In the spirit of the above, there is another trend and this is a combination of quantitative and qualitative evaluation by teachers. In most schools, output evaluation is a mark, i.e. a quantified output. Parents don't usually require any other method of evaluation. And in most cases, even the schools don't expect teachers to perform any other form of evaluation. However, interestingly, teachers use a combination of classification and verbal evaluation, although they're not forced to do so because they feel that the mark itself can't express enough of what pupils master or not.

I use it at class meetings, when every parent just receives a mark suggested by myself, I have a box and a space for each course for announcement such as a verbal evaluation, that means there is for example, the best mark and I just write in there what they should improve what they should work harder on or a course in which their mark hasn't been decided yet and so on. It isn't used by any of my colleagues, but I need it. And then, of course, there are also individual interviews with parents and the children and I also constantly evaluate children verbally in lessons. (Marie)

Individualisation is an important element of current school evaluation. Teachers take it as a matter of course, although they admit themselves that it's a demanding and requires very good knowledge of pupils and colleagues. At the same time, it requires a high qualification of the teacher in the evaluation issue, so that the principle of individualisation is indeed beneficial for the pupil, and not an inappropriate advantage for the pupil.

I evaluate each child differently, individually. Some have a pedagogical support plan. Some don't. I evaluate someone with a mark; sometimes I evaluate everything with a mark, sometimes only something. I evaluate some children with mark and orally. There are many ways, it depends on the course and the matter, the stage we are at, the training or practice and already fixed curriculum. (Kristina) 
An important element to individualise the evaluation is to work with a group. It's well known that children have a very developed sense for justice and very sensitively perceive any indication of favouritism or disadvantage their own or other children. For this reason, teachers need to work very sensitively, especially with younger children, work with and teach them to perceive it differently, considering the differentness, individuality and the way of evaluation. Teachers themselves point out that, especially at the beginning of schooling, children need to be actively involved in this skill.

When the team is working so that children are used to helping each other. When I use it as a teacher, pupils that are more talented and faster at work help me with the weaker ones, yeah, so they don't perceive it as badly. I don't have any bad experiences with this, I think it's about how the teacher directs the lesson, how they work with these children. (Jana)

One of the significant trends in the current school evaluation should be mentioned, i.e. the support for self-evaluation for pupils. It's practically identical for respondents that in today's modern society have to be able to critically evaluate their performance in order to be able to develop professionally as well as personally. Therefore, teachers show great importance in developing this skill. They are convinced that in the younger school age, pupils in co-operation with the teacher, are able to assess their performance and the performance of others. Training for this skill takes place at the beginning of school life. Accordingly, they add that there is a significant difference between children according to the family background.

I think that it's also important for the team position then. Yeah, those who have overwhelming self-esteem or, on the contrary, some children have very low self-esteem, then I work with it with my parents. ...maybe I ask hem "what do you think would happen if you didn't do it?" When I know that I lead them to realise that if you work hard, it will work out. Some get it straight away, others need longer, unfortunately that's the way it is, but in the end, when you don't give up the fight, it's possible. (Petra)

\section{Summary}

The results point to a change in evaluation methods in the context of the transformation of the educational paradigm. With the transition from the transmissive approach to constructivism, there is also a transformation of the thinking of teachers who put more emphasis on the development of the personality of the individuals more than on the quantifiable aspect of the evaluation. In line with the cultural tradition of the Czech Republic, mainly because of the parental pressure and often also children, a mark still prevails as an expression of objective evaluation. However, teachers include elements of verbal evaluation that help to differentiate what the mark actually means.

Within this framework, the so-called formative evaluations are increasingly used. Formative evaluation is a type of evaluation that takes place during learning and provides pupils with useful information during the learning process. The teacher must take care that the pupils know and accept the aim of the lesson so they think about it and understand it. They also have to make sure they recognise the quality to know how to learn whether they have or failed to reach the goal. Teaching must be built in such a way that the teacher has an idea during the lesson on where each child is in the process of understanding (cards, semaphores, etc.). The lesson should 
include an opportunity for mutual evaluation among pupils and finally a space for self-evaluation.

Self-evaluation is a means of informal education and focuses on both the course and the outcome of school work. This means that it's aimed at increasing the effectiveness of the pupil's process of achieving cognitive, affective, social and psychomotor goals, not prioritising in comparison with the performance of classmates, but with regard to a predetermined criterion regardless of their classmates performance. Errors are detected in a pupil's work and self-evaluation is the starting point for eliminating mistakes by analysing causes and drawing consequences. Its main goal is to support student autonomy and independence and to develop an authentic personality.

\section{Acknowledgement}

This research was financially supported by a specific research project for the Faculty of Education, University of Hradec Králové in 2018 Types of evaluation at primary school level from the teachers' point of view.

\section{References}

[1] Z. Kolář, R. Šikulová, Hodnocení žáků [Evaluation of pupils], Grada, Praha, 2009

[2] Z. Kolář, A. Vališová, Analýza vyučování [Analysis of education], Grada, Praha, 2009.

[3] J. Slavík, Hodnocení v současné škole [Evaluation in contemporary school], Portál, Praha, 1999.

[4] J. Čáp, J. Mareš, Psychologie pro učitele [Psychology for teachers], Portál, Praha, 2001.

[5] J. Mareš, Pedagogická psychologie [Educational psychology], Portál, Praha, 2013.

[6] A. Vališová, H. Kasíková, Pedagogika pro učitele [Pedagogy for teachers]. Grada, Praha, 2011.

[7] M. Weimer, Learner-centered teaching - Five key changes to practice, Jossey-Bass,San Francisco, 2013

[8] K. Starý, V. Laufková, Formativní hodnocení ve výuce [Formative evaluation in education], Portál, Praha, 2016

[9] G. Petty, Teaching today, Nelson Thornes, 2009.

[10]A. Rakoušová, Sebehodnocení žáků [Self-evaluation of pupils], Metodický portál RVP, Retrieved from http://clanky.rvp.cz/clanek/s/Z/1965/SEBEHODNOCENI-ZAKU.html/ [11]D. Silverman, Doing Qualitative Research. Sage, 2013

[12]R. Yin, Qualitative Research from Start to Finish, New York \& London, The Guilford Press, 2011 